\title{
1 Introduction: Human Rights Past, Present, and Future
}

\author{
Stephen Hopgood, Fack Snyder, and Leslie Vinjamuri
}

International human rights NGOs and institutions have been at the vanguard of multiple advocacy campaigns designed to galvanize global support for human rights. The impact of these initiatives has been dramatic. States have adopted human rights conventions, ratified treaties, supported new human rights committees and courts, and extended the mandate of existing international and regional organizations to include human rights. The sheer growth of human rights NGOs and the increased reference to human rights by states, international organizations, and other actors shows that human rights are now a major focal point for transnational mobilization. The global middle class, widely seen as a mainstay of human rights observance, is projected to increase from 1.8 billion in 2012 to 3.2 billion by $2020 .^{1}$

Human rights research has also found cause for optimism. Some scholars argue we are living through a 'justice cascade' where transnational movements for human rights allied to international law have made accelerating gains in the elimination of human rights violations such as torture. ${ }^{2}$ Some have even claimed that cruelty and killing are in decline,

${ }^{1}$ Homi Kharas and Geoffrey Gertz, "The New Global Middle Class: A Cross-Over from West to East," in Cheng Li (ed.), China's Emerging Middle Class, Beyond Economic Transformation (Washington DC: Brookings Institution Press, 2010). Although much of the projected growth is expected to take place in China and India where human rights advocates have so far struggled to make headway, the emergence of a global middle class is likely to narrow the material and cultural divides that slow the emergence of a global set of values. The mass of global polling data collected in the World Values Survey (WVS) provides empirical evidence of how economic development leads to value changes conducive to democracy. European Strategy and Policy Analysis System (ESPAS), Global Trends 2030 - Citizens in an Interconnected and Polycentric World, European Union Institute for Security Studies, 2012, p. 29: www.iss.europa.eu/publications/detail/article/espasreport-global-trends-2030-citizens-in-an-interconnected-and-polycentric-world/.

${ }^{2}$ Kathryn Sikkink, The fustice Cascade: How Human Rights Prosecutions Are Changing World Politics (New York: W. W. Norton \& co, 2011); Margaret Keck and Kathryn Sikkink, Activists Beyond Borders: Advocacy Networks in International Politics (Ithaca: Cornell University Press, 1998); Beth A. Simmons, Mobilizing for Human Rights: International Law 
due in no small part to the rights revolution. ${ }^{3}$ Others suggest that even in a world where Western powers no longer dominate, international liberal norms embedded in global institutions will endure. ${ }^{4}$ These advocacy and scholarly claims all sustain a hopeful story in which the future for human rights mobilization is a positive and enduring one.

But, as many of the chapters that follow will argue, this is not the only possible future for human rights. Alternative accounts to the mobilization narrative see a future that is much more one of ambivalence, ineffectiveness, failure, and even irrelevance. We group these critiques under four headings: scope conditions, backlash, localization, and utopias and endtimes.

Scope conditions for successful human rights activism include embedding mobilization within a broader social movement for political change that harnesses actors with varying motivations to the cause, an alliance with power to realize human rights ends when persuasion is not enough, and the material capacity of states to make real the legal commitments they have made. These favorable conditions hold when countries are at peace and when they already enjoy some institutional, economic, and social facilitating conditions for democracy. But the countries where rights abuses are worst are what we will call "hard cases," which lack these favorable conditions. Outside the scope conditions for the success of conventional mainstream approaches to rights advocacy, pragmatic innovations may be necessary.

Human rights mobilization not only fails because of its lack of anchorage in social coalitions, its inadequate alliance with state power, or a lack of state capacity, it also faces resistance. Backlash is driven by those threatened by human rights and powerful enough to resist. They sometimes exploit the opportunity to reframe or even demonize global rights to mobilize the many against the rights message, while at other times more subtle methods of non-engagement and resistance are employed. Backlash encompasses a wide variety of strategies, in other words, ranging

in Domestic Politics (Cambridge: Cambridge University Press, 2009); Christopher J. Fariss, "Respect for Human Rights Has Improved over Time: Modeling the Changing Standard of Accountability," American Political Science Review 108, no. 2 (2014): 297-318; Ann Marie Clark and Kathryn Sikkink, "Information Effects and Human Rights Data: Is the Good News about Increased Human Rights Information Bad News for Human Rights Measures?" Human Rights Quarterly 35, no. 3 (August 2013): 539-68; Jo Becker, Campaigning for Fustice: Human Rights Advocacy in Practice (Stanford: Stanford University Press, 2012); Alison Brysk, Speaking Rights to Power: Constructing Political Will (New York: Oxford University Press, 2013).

${ }^{3}$ Steven Pinker, The Better Angels of Our Nature: A History of Violence and Humanity (London: Penguin, 2012); Joshua S. Goldstein, Winning the War on War: The Decline of Armed Conflict Worldwide (New York: Plume Books, 2012).

${ }^{4}$ G. John Ikenberry, Liberal Leviathan: The Origins, Crisis and Transformation of American World Order (Princeton: Princeton University Press, 2011). 
from confrontation (openly resisting the obligations rights impose), to evasion (ignoring rights demands) or instrumentalization (e.g., using rights language to justify repressing individual speech or due process to protect the "rights of the community"). Democracies as well as autocracies can engage in behavior along this spectrum.

In an era that is marked by increasing political upheaval not only in many parts of the Global South, but also in the United States and Europe, we ask the question of whether backlash is increasing and what this means for human rights going forward. The recent assault on human rights in the United States provides a laboratory for evaluating the role of domestic institutions, civil society, and norms in securing human rights. Protests in support of rights in the weeks following the election of Donald Trump also remind us that backlash can be deployed in favor of, and not only against, human rights. Like previous critiques, backlash theorists underscore the need to trim unbending principles in the face of political reality. Pursuing some rights, such as religious freedom, may at times be counterproductive. Similarly, backlash in support of rights faces the challenge of tailoring principle to politics.

Human rights as they are understood in Western capitals have often been poorly integrated in struggles for freedom and equality in the South. To be effective, a greater awareness of local needs, actors, and strategies manifest in different forms of advocacy, and in alternative campaign priorities - may be essential to achieve positive results. We label this localization. The most influential account of this process, where global principles are translated into local struggles, has been termed 'vernacularization' and we examine it in depth. We also acknowledge the agency that local human rights actors often display by examining how they use human rights in their own customized ways to achieve their priorities. This is all 'human rights activism,' but it may not look much like the human rights with which we are familiar.

Finally, in utopias and endtimes, some scholars ask whether there is really any future at all for human rights. They suggest that human rights may represent a mistaken path taken on the road to delivering more genuine freedom and equality, an illusion of a post-ideological world of liberal freedoms that actually serves to deflect us from real progress toward social and economic justice. Others claim that human rights may be an artifact of a postcolonial world dominated by Western states that are declining in the face of newly emerging non-liberal global powers, revitalized nationalism, resurgent religion, and the refusal of the middle classes to part with any of their privilege.

Although normative discussions are in evidence throughout the volume, we do not deal explicitly with the moral and philosophical basis 
of human rights. Questions about the foundations and justification of rights, about what a right is, what kinds of rights there are, about universality, about the conception of the person underlying rights, whether that person must necessarily be conceived in 'liberal' terms, the justifiability of natural rights claims, whether political rights have priority, deontology vs. utilitarianism, and the role of dignity as a moral foundation for rights are not explicitly addressed for three reasons.

First, other recent works have considered these normative issues in forensic detail. ${ }^{5}$ Second, normative arguments can be made for or against both human rights as such, and against certain rights in particular. Such moral claims as these admit of no empirical resolution. However, for some participants in these normative debates, it makes a difference whether and how rights can be instantiated in specific real world conditions: ought implies can. In this spirit, we focus on what makes the difference in everyday success for human rights - the alignment of social and political forces, globally, nationally, and locally, and the interests they pursue, including but not limited to those in greater equality or freedom.

Third, following on from this, we see many of the sharpest debates about human rights at the present juncture as about the feasibility of making rights a reality and what tactics to use in pursuing that goal. So, while we do have chapters that stake out opposing normative positions in the debate, and while almost all the chapters discuss norms and normative beliefs as empirical facts, we focus in the main on the politics of making rights real rather than the strength of the moral argument behind them.

In Section 1, we give due attention to what are, on the face of it, the remarkable achievements of generations of human rights advocates. Following this, in Section 2, we take an audit of scholarship into human rights. In Section 3 we outline the four critiques introduced above in more depth. Section 4 is a brief conclusion.

\section{Globalizing Human Rights}

The emergence of human rights as a global discourse was the culmination of a long historical process. There is no consensus on the social and

\footnotetext{
${ }^{5}$ See, for example, Rowan Cruft, S. Matthew Liao, and Massimo Renzo (eds.), Philosophical Foundations of Human Rights (Oxford: Oxford University Press, 2015); Cindy Holder and David Reidy (eds.) Human Rights: The Hard Questions (Cambridge: Cambridge University Press, 2013); Costas Douzinas and Conor Gearty (eds.), The Meanings of Rights: The Philosophy and Social Theory of Human Rights (Cambridge: Cambridge University Press, 2014).
} 
political origins of human rights. ${ }^{6}$ Rights-like ideas and practices have been dated to antiquity, Roman law, late medieval European politics, Calvinism, the middle ages, and the evolution of humanist sensibilities in the eighteenth and nineteenth centuries. ${ }^{7}$ The most influential narrative sees post-Enlightenment European revulsion with torture and slavery at the heart of a linear account of liberal progress, this "revolution in moral sentiment" then globalized in the name of civilization through the vector of empire. ${ }^{8}$ Its culmination came in the period immediately following World War II and the Holocaust, when human rights were embedded through a series of bold institutional developments such as the Nuremberg trials, the Charter of the United Nations, the Universal Declaration of Human Rights, the Genocide Convention, and the revised Geneva Conventions.

Searching recent reassessments of this account have stressed the disjuncture between the 1940s and the 1970s. Rather than seeing human rights progress as a linear development, more attention is given to the lesser role that responses to the Holocaust actually played in stimulating human rights institutions in the immediate postwar period, and the ways rights displaced alternative organizing principles for justice and freedom (e.g., socialism, national self-determination). The role of non-Western actors in stimulating rights developments in the 1960s, particularly at the $\mathrm{UN}$, also fits within this critical revisionism. ${ }^{9}$

${ }^{6}$ For recent historical scholarship see: Stefan-Ludwig Hoffmann, ed., Human Rights in the Twentieth Century (New York: Cambridge University Press, 2011); Akira Iriye, Petra Goedde, and William I Hitchcock (eds.) The Human Rights Revolution: An International History (New York: Oxford University Press, 2012); Samuel Moyn. The Last Utopia: Human Rights in History (Cambridge, MA: Belknap/Harvard University Press, 2010); Elizabeth Borgwardt, A New Deal for the World: America's Vision for Human Rights (Cambridge, MA: Belknap/Harvard University Press, 2005).

${ }^{7}$ Micheline R. Ishay, The History of Human Rights: From Ancient Times to the Globalization Era (Oakland: University of California Press, 2008); Christian Reus-Smit, Individual Rights and the Making of the International System (Cambridge: Cambridge University Press, 2013); Lynn Hunt, Inventing Human Rights: A History (New York: W. W. Norton \& Co, 2007); Paul Gordon Lauren, The Evolution of International Human Rights: Visions Seen, 2nd edn. (Philadelphia: Penn Press, 2003); Mary Ann Glendon, $A$ World Made New: Eleanor Roosevelt and the Universal Declaration of Human Rights (New York: Random House, 2001); Aryeh Neier, The International Human Rights Movement: A History (Princeton: Princeton University Press, 2012); Roger Normand and Sarah Zaidi. Human Rights at the UN: The Political History of Universal fustice (Bloomington: Indiana University Press, 2008); Moyn, The Last Utopia.

${ }^{8}$ Hunt, Inventing Human Rights, but also Stephen Hopgood, The Endtimes of Human Rights (Ithaca: Cornell University Press, 2013).

9 The most influential account is Moyn, The Last Utopia. See also Steven L. B. Jensen, The Making of International Human Rights; The 1960s, Decolonization, and the Reconstruction of Global Values (New York: Cambridge University Press, 2016). 
What is less contested in most of these histories is the importance of the 1970s as the moment of take-off for the modern human rights revolution, and of the 1990s as the decade in which human rights achieved truly global stature. ${ }^{10}$ President Jimmy Carter made human rights a centerpiece of US foreign policy in 1977, the same year Amnesty International won the Nobel Peace Prize and a year before Helsinki Watch, the forerunner of Human Rights Watch, was formed. Building on international covenants on civil and political, and economic, social, and cultural rights ratified in the mid-1970s, conventions were established on discrimination against women (1981), against torture (1987), and on children's rights (1989). The UN secretary-general Boutros Ghali's Agenda for Peace of 1992 even announced a new era where human rights would increasingly impose conditions on legitimate sovereignty. ${ }^{11}$

As the Cold War ended, the era of institutionalized human rights familiar to us today gathered pace with 1993's UN Conference on Human Rights in Vienna, which established the UN Office of the High Commissioner of Human Rights. This was followed by ad hoc tribunals for Yugoslavia (1993) and Rwanda (1994), the Rome Statute (1998) and the International Criminal Court (2002), the Responsibility to Protect (2001/2005), the new Human Rights Council (2006), and the Universal Periodic Review (2008). These were all significant developments in the law and compliance regime of human rights. Many other agreements and institutions were set up or revitalized, at the regional and national levels, and soon almost all advocates who sought progress on norms and their implementation - from migrants to indigenous people to the disabled to those fighting against female genital mutilation - expressed their demands in the language of human rights. Even humanitarian organizations such as the ICRC and Oxfam followed suit.

Human rights are also now central to international condemnations of atrocity crimes by states. The UN's detailed report on the appalling conditions in which people live in North Korea, released in February 2014, uses human rights and their most far-reaching legalized expression - crimes against humanity - as the framework for demanding both referral to the ICC (now backed by the UN General Assembly) and even the use of coercive pressure under the label of R2P. ${ }^{12}$ High-profile human rights

${ }^{10}$ Barbara J. Keys, Reclaiming American Virtue: The Human Rights Revolution of the 1970s (Cambridge, MA: Harvard University Press, 2014).

${ }^{11}$ UN Security Council, An Agenda for Peace: Report of the Secretary-General Pursuant to the Statement Adopted by the Summit Meeting of the Security Council on 31 fan 1992. June 17, 1992.

12 Report of the detailed findings of the commission of inquiry on human rights in the Democratic People's Republic of Korea, A/HRC/25/CRP.1, February 2014, available at: 
campaigns - over Israeli shelling of Gaza, ISIS in Iraq, or civil war in Syria - now get publicity on a global scale. Within the UN system, there has been a major institutional shift with the implementation of a 'Rights Up Front' policy following what was seen as the UN's failure to protect human rights during the end of the Sri Lankan civil war in 2009. It is intended to embed human rights in every aspect of the UN's operational work. $^{13}$

As for the future, various initiatives are currently being proposed whose aim is to fully globalize the reach of human rights law. For example, a convention on crimes against humanity is being discussed within the International Law Commission (as the Rome Statute was initially). ${ }^{14}$ This convention will, advocates hope, be a powerful tool for condemning the worst state excesses, applying in peacetime as well as in war and filling in several gaps that the current network of treaties leaves open. Advocates for the convention even hope it might give impetus to prosecuting the crime of aggression, the fourth major international crime under the Rome Statute. As crimes against humanity are considered to be customary international law, this would open up almost all state behavior to binding legal accountability.

Second, the most ambitious proposal of all is perhaps a Swiss-led initiative for a World Human Rights Court. This court, while treaty-based, would apply to non-state actors as well as states, and would allow complaints to be heard against non-parties to the statute provided they were supported by the UN High Commissioner for Human Rights (in which case, they would constitute opinions, not legally binding judgments). The court would also be able to rule on the permissibility of reservations entered by states to human rights treaties. ${ }^{15}$ The ICC's focus on individual criminal responsibility would be augmented by the WCHR's focus on state and non-state actor responsibility. The court might even, its advocates suggest, exercise judicial review of Security Council decisions. ${ }^{16}$

www.ohchr.org/EN/HRBodies/HRC/CoIDPRK/Pages/ReportoftheCommissionofInqu iryDPRK.aspx.

${ }^{13}$ www.un.org/sg/en/content/ban-ki-moon/human-rights-front-initiative.

${ }^{14}$ See the Crimes Against Humanity Initiative, Fulfilling the Dictates of Public Conscience: Moving Forward with a Convention on Crimes Against Humanity, Washington St Louis School of Law (2014): http://law.wustl.edu/harris/documents/Final-CAHGenevaReport -071714.pdf, and Leila Nadya Sadat (ed.), Forging a Convention for Crimes Against Humanity (Cambridge: Cambridge University Press, 2014).

${ }^{15}$ Martin Scheinin, "Towards a World Court for Human Rights," advanced copy, European University Institute, June 2009, p. 8 (available at: www.eui.eu/Documents/ DepartmentsCentres/AcademyofEuropeanLaw/CourseMaterialsHR/HR2009/Scheini $\mathrm{n} /$ ScheininClassReading1.pdf).

${ }^{16}$ Ibid., 26. In a withering critique, Philip Alston finds the idea of the court thoroughly misconceived, a distraction from the difficult business of improving human rights by 
This overview of significant institutional achievements gives us a sense of the aspirational character of the global human rights regime. ${ }^{17}$ All of these developments in theory move us closer to the advocacy ideal of a global constitution, a set of binding laws about appropriate behavior by states, non-state actors, and individuals alike. In fact, though, each of these institutions has embedded protections for states, and exceptions or even exemptions for especially powerful ones. The ultimate prize - a law without boundaries, with universal jurisdiction, beyond explicit state consent that would move us "from consent to constitution," from "a state-centred world order to a new global order with [a] focus on the individual endowed with rights" - has been heavily compromised. ${ }^{18}$ Institutional design rarely reflects the aspiration of advocates who seek a world where due process and the rule of law hold superior authority to state practice.

\section{An Audit of Human Rights Scholarship}

Empirical research on human rights has flourished over the past two decades, moving from a productive early phase of empirical theory development into a more recent phase of sophisticated, multi-method research and debate among different theoretical approaches and inference strategies. This research has been explanatory as well as descriptive, quantitative as well as qualitative, experimental as well as observational, and aimed at the development as well as the testing of theory. ${ }^{19}$ Over time, claims for a difference in results based on method have been inconclusive. ${ }^{20}$ Rather, different methods have complementary strengths that can compensate for corresponding weaknesses, with quantitative methods best at assessing general patterns and qualitative methods stronger at verifying

non-judicial as well as judicial means, which requires giving more attention to certain political realities; see "Against a World Court for Human Rights," Ethics and International Affairs, no. 2 (2014): 197-212.

${ }^{17}$ See Ruti Teitel, Humanity's Law (Oxford and New York: Oxford University Press, 2011).

${ }^{18}$ Scheinin, Towards a World Court, 9. Also Stephen Gardbaum, "Human Rights and International Constitutionalism," in Ruling the World: Constitutionalism, International Law, and Global Governance, edited by Jeffrey L. Dunoff and Joel P. Trachtman (Cambridge: Cambridge University Press, 2009), 233-57.

${ }^{19}$ Emilie Hafner-Burton and James Ron, "Seeing Double: Human Rights Impact through Qualitative and Quantitative Eyes," World Politics 61, no. 2 (April 2009): 360-401. For a randomized experiment on women's empowerment in Afghan villages, see Andrew Beath, Fotini Christia, and Ruben Enikolopov, "Empowering Women through Development Aid: Evidence from a Field Experiment in Afghanistan," American Political Science Review 107, no. 3 (August 2013): 540-57.

${ }^{20}$ Although compare, for e.g., Simmons' and Clark's largely confirmatory studies with Moyn's and Hopgood's largely skeptical historical and ethnographic studies. 
causal mechanisms. As a result, researchers have converged on a substantial core of consensual findings on the conditions that facilitate good human rights outcomes.

\section{Consensus About Facilitating Conditions for Rights}

Broad consensus exists across all kinds of empirical researchers, including quantitative and qualitative, as well as critics and defenders of mainstream practices, about the conditions that promote and hinder positive rights outcomes. Quantitative studies report that two factors are the most important predictors of the quality of rights outcomes in a country: whether the country is at peace or at war, and how democratic the country is. Some might see the democracy finding as bordering on the circular, since most measures of democracy assume the existence of the civil liberties and legal apparatus that makes democracy possible. And so it is. But many of the other strong findings about the correlates of good rights outcomes are either causes, attributes, or consequences of democracy, which suggests that the link between democracy and rights is not just a tautology, but is based on a complex of mutually supporting causal factors that sustain rights outcomes. These include a reasonably high per capita income, which is the single strongest predictor of democracy; a fairly strong institutional capacity of the state, including an effective, impartial bureaucracy as well as strong representative and legal institutions, sometimes measured by the rough proxy of being a former British colony; and a progressive, socially inclusive ruling coalition that is "on the left."21

Findings about the risk factors for rights also echo findings for democracy. Economic inequality undermines both rights and democracy. ${ }^{22}$ A large population is likewise a risk factor for rights abuse, possibly because of the difficulty of democratically governing culturally diverse peoples in a single state. ${ }^{23}$ Some findings also suggest that there is "more murder in the middle": democratizing states endure similar levels of rights abuse to authoritarian states as a result of contentious mass mobilization in a context of weakly developed institutions for regulating mass political participation. These studies find that any benefit from

${ }^{21}$ Steven C. Poe, Neal Tate, and Linda Camp Keith, "Repression of the Human Right to Personal Integrity Revisited: A Global Cross-National Study Covering the Years 1976-1993.” International Studies Quarterly 43, no. 2 (1999): 291-313.

22 Todd Landman and Marco Larizza, "Inequality and Human Rights: Who Controls What, When, and How," International Studies Quarterly 53, no. 3 (2009), 715-36.

${ }^{23}$ In some studies, though, this apparent finding may stem from a failure to weight results by population. 
democratization accrues only after passing a rather high threshold to nearly complete democracy. ${ }^{24}$ Another well-established literature, in contrast, finds that treaty-signing and mainstream methods of legal and activist follow-up have their greatest benefit for rights improvement in democratizing states. ${ }^{25}$

These seemingly contradictory findings could be simultaneously true if violations rise mainly at the early phases of transition, when democracy is very poorly institutionalized, and they decline in the more advanced phases of transition. Alternatively, it could be that democratizers "in the middle" are deadly unless they enjoy favorable facilitating conditions, which mainstream rights methods try to encourage by treaty signing, NGO activism, and lobbying for judicial independence.

These statistical results track fairly closely with the list of limiting conditions set out by qualitative scholars for evaluating the spiral model of rights promotion, which is based on the establishment of legal and moral standards and the shaming and coercion of violators. The Persistent Power of Human Rights argues that such methods are less effective in authoritarian regimes, in very weak and very strong states, in issue areas where violations are socially decentralized, and where the rights-abusing state enjoys popular support. ${ }^{26}$ Persistent Power's summary list of facilitating scope conditions omits peace and per capita income, though these are implied in some of the empirical chapters. One, for example, notes that protecting rights becomes an "almost insurmountable" task in wartime, though some rebels may be restrained by a concern not to gain a reputation for being lawbreakers. ${ }^{27}$

${ }^{24}$ Bruce Bueno de Mesquita, Feyral Marie Cherif, George Downs, and Alastair Smith, "Thinking Inside the Box: A Closer Look at Democracy and Human Rights," International Studies Quarterly 49, no. 3 (2005), 439-58; Helen Fein, "More Murder in the Middle: Life Integrity Violations and Democracy in the World, 1987," Human Rights Quarterly 17, no. 1 (1995), 170-91. Simmons, Mobilizing for Human Rights, refers to this literature on p. 136, note 84. See also Christian Davenport and David Armstrong, "Democracy and the Violation of Human Rights: A Statistical Analysis from 1976 to 1996," American Fournal of Political Science 48, no. 3 (2004), 538-54. See also Samuel Huntington, Political Order in Changing Societies (New Haven: Yale University Press, 1968), for relevant theory.

${ }^{25}$ Simmons, Mobilizing for Human Rights, 153; Davenport and Armstrong, "Democracy and the Violation of Human Rights," 547; Fein, "More Murder in the Middle," 177, $179,181,183$. Simmons' graph of the theoretically expected value of political mobilization begins to arc upward as soon as autocracy ends, whereas Davenport's and Fein's charts of actual outcomes show rights abuse remaining high and even trending slightly up at that point and declining only in complete democracy.

${ }^{26}$ Risse, Ropp, and Sikkink (eds.), Persistent Power; see also Kenneth Roth, "Africa: The Attacks on the International Criminal Court," New York Review of Books, February 6, 2014, 32-5.

${ }^{27}$ Hyeran Jo and Katherine Bryant, "Taming of the Warlords," in Risse, Ropp and Sikkink (eds.), Persistent Power, 239. 


\section{Overall Trends in Human Rights Outcomes}

Notwithstanding the consensus on facilitating conditions for rights in general, there is much less consensus in the research on outcomes and on the effects of tactical interventions designed to improve rights in a specific setting. Here, the research findings are often contradictory, limited by problems of data and research design, hedged by conditional hypotheses that are not yet corroborated by replicating or extending studies, or simply absent.

However, even when the full battery of methods is used in mutually supportive ways, the field still faces methodological challenges. Some originate in data problems. For example, comparing trends in human rights compliance over time is difficult because awareness of abuses and data collection has changed. Likewise, scales for measuring abuses that were designed to highlight the existence of even small numbers of rights violations may be insensitive to larger differences in the number of violations at the higher end of the scale. ${ }^{28}$ More intractable are inference problems that hinge on unobservable or unmeasureable factors. For example, James Meernik et al. note that the power of rights-abusing spoilers is central to theories about the effects of trials on human rights, but, like the rest of the quantitative literature, their study lacks any way to measure this variable or include its conditional effects in the analysis. ${ }^{29}$ Even qualitative studies have only had limited success so far in conceptualizing the power of spoilers in a way that permits reliable comparison across cases and causal process tracing. ${ }^{30}$

Critics of prevailing human rights strategies also argue that statistical measures of most rights outcomes, defined in terms of treaty compliance, have not improved in recent decades, despite the intense rhetoric and mobilization of the global rights movement. ${ }^{31}$ Defenders of the achievements of the human rights movement argue that the apparent lack of progress is an optical illusion: improved data has turned up violations that previously would have gone unreported. ${ }^{32}$ They also argue that real

${ }^{28}$ Clark and Sikkink, "Information Effects and Human Rights Data."

${ }^{29}$ James Meernik, Kimi King, and Angela Nichols, "The Impact of International Tribunals and Domestic Trials on Peace and Human Rights after Civil War," International Studies Perspectives 11, no. 4 (2010): 309-34.

${ }^{30}$ Kelly Greenhill and Solomon Major, "The Perils of Profiling: Civil War Spoilers and the Collapse of Intrastate Peace Accords," International Security 31, no. 3 (Winter 2006/ 07): 7-40.

${ }^{31}$ Emile M. Hafner-Burton, Making Human Rights a Reality (Princeton: Princeton University Press, 2013), 3. Improved data cuts both ways, civil war researchers frequently adjusting their numbers downward as time passes and information improves.

32 Fariss, "Respect for Human Rights Has Improved Over Time," proposes a very complex, indirect method for calibrating biases in measuring rights violations due to increased data availability, and historically changing standards, by making use of comparisons to continually updated historical data on the worst atrocities. He claims this technique shows 
improvements have occurred in some countries, especially democratizing countries that have signed human rights treaties, but not in countries that lie outside the scope conditions of current approaches. ${ }^{33}$ Finally, they argue that it is too soon to judge the success of mainstream rights strategies, because strengthening global norms through persuasion and institutionalization is necessarily a gradual process. For example, despite the ICC's minimal conviction rate and Africa-dominated docket, they emphasize that the institutional base for future success has been established. ${ }^{34}$ Thus, the lack of consensus is based on disputes about the validity of data and on theoretically informed differences about how to interpret evidence.

\section{Tactical Interventions to Improve Rights}

There is only partial consensus about the effects of different tactics, with limited convergence reflecting underlying agreement about scope conditions. Research suggests that mainstream rights approaches work well mainly in what might be called easy cases: countries that are already fairly democratic, have respectable administrative capacity, have somewhat independent courts, and tolerate robust activism by principled civil society groups. ${ }^{35}$ There is little agreement, however, on the effects of different tactics in harder cases.

Results of statistical studies of shaming tactics, for example, are inconsistent and difficult to interpret. Many studies have attempted to identify the conditions in which shaming works, but with little convergence so far. Some studies find that shaming is often ineffective or even counterproductive, leading, for example, to backlash (see chapters by Vinjamuri, and Cooley and Schaaf, this volume). Hafner-Burton, based on statistical findings and numerous brief illustrations, finds that shaming is generally correlated with improvements in political rights but not physical integrity rights. She concludes that denunciations can have a "whack-a-mole" effect, leading the abuser to shift from more visible repression to other forms. ${ }^{36}$ Jennifer Lind's detailed monograph, Sorry States, finds that

that rights outcomes are improving. Though an intriguing step forward, this methodology requires making several heroic assumptions, including confidence in updated atrocities data, which remains highly politicized. See Peter Andreas and Kelly M. Greenhill (eds.) Sex, Drugs, and Body Counts: The Politics of Numbers in Global Crime and Conflict (Ithaca: Cornell University Press, 2010), chapters 1, 6, 7, 8, and 11.

33 Clark and Sikkink, "Informational Effects"; Simmons, Mobilizing for Human Rights.

34 Thomas Risse and Kathryn Sikkink, "Conclusions," Persistent Power, 281-2, 294.

${ }^{35}$ Simmons, Mobilizing for Human Rights.

${ }^{36}$ Emilie Hafner-Burton, "Sticks and Stones: Naming and Shaming the Human Rights Enforcement Problem." International Organization 62, no. 4 (Fall 2008): 689-716; 
repeated international demands that Japan apologize for its World War II atrocities have played into the hands of Japanese nationalists who were lobbying for official visits to the Shinto shrine where war criminals are interred. ${ }^{37}$ Other studies stress more positive findings, many of them trying to identify the conditions under which shaming is effective. Ann Marie Clark, illustrating her statistical study with the example of Indonesia, finds that shaming reduces rights abuse in countries that have ratified rights treaties, even if they are non-democracies. ${ }^{38}$ An entirely statistical study by Matthew Krain found that shaming reduced the severity of 29 genocides and mass killings from 1976 to $2008 .^{39}$ Another entirely statistical study by Amanda Murdie and David Davis, offered as a test of the spiral model, finds that shaming by human rights organizations improves human rights if local human rights activists are numerous and if third parties such as states echo the denunciations of the activists. ${ }^{40}$

Why do these studies find such varied results? One reason may be that they ask somewhat different questions, advancing hypotheses that are qualified in different ways, using different databases and research designs, and covering different time periods. ${ }^{41}$ The influential study by Murdie and Davis also raises the issue of how to interpret causality in a multifaceted interaction among (1) shaming by rights organizations in a setting in which (2) the flourishing of local rights organizations is not

Darius Rejali makes a similar argument, claiming that pressure from human rights advocates has driven states to adopt torture techniques that are less visible; see Darius Rejali, Torture and Democracy (Princeton: Princeton University Press, 2008). A factor that is not sufficiently taken into account by some of these studies is that disproportionate publicity may be aimed at recalcitrant actors that are hardest to change. If this were so, results would be biased against shaming tactics.

37 Jennifer Lind, Sorry States: Apologies in International Relations (Ithaca: Cornell University Press, 2008). See also Jelena Subotic, Hijacked fustice: Dealing with the Past in the Balkans (Ithaca: Cornell University Press, 2009).

38 Ann Marie Clark, "The Normative Context of Human Rights Criticism: Treaty Ratification and UN Mechanisms," in Risse, Ropp, and Sikkink, Persistent Power, chapter 7, p. 143.

${ }^{39}$ Matthew Krain, "J'accuse! Does Naming and Shaming Perpetrators Reduce the Severity of Genocides or Politicides?” International Studies Quarterly 56, no. 3 (2012): 574-89.

${ }^{40}$ Amanda M. Murdie and David R. Davis, "Shaming and Blaming: Using Events Data to Assess the Impact of Human Rights INGOs," International Studies Quarterly 56, no. 1 (2012): 1-16.

${ }^{41}$ For example, the outcome variable in the Murdie and Davis study is improvement in physical integrity rights, coded yes or no. Since they find no effect when they use what they call the "raw scores" for physical integrity rights, it may be that their reworked measure is picking up very small improvements, which they magnify by their practice of binary coding. The lack of even the briefest case illustrations further hinders the effort to understand why studies report diverse findings. See also Oskar N. T. Thoms, James Ron, and Roland Paris, "State-level Effects of Transitional Justice: What Do We Know?" International fournal of Transitional fustice 4, no. 3 (2010): 329-54. 
suppressed by the state and (3) powerful outside parties, including states, are also exerting pressure. Because all of these elements are included in the spiral model, it is hard to tell whether shaming per se is doing much causal work. A number of these studies imply that the scope conditions for effective shaming may be quite narrow, putting its usefulness as a widespread advocacy tactic in doubt.

\section{Implications of Social Science Findings for Advocacy}

From this preliminary audit, on which the chapters below reflect both explicitly and implicitly, we draw an important conclusion. Despite the sophistication of much contemporary scholarship, the only broad consensus is on the background conditions that facilitate human rights success (essentially, peace and democracy). Disagreement continues among scholars over what the available data says about human rights outcomes in general, and specific interventions in particular. Building on the groundbreaking earlier work of Sikkink and Simmons, the chapter in Human Rights Futures by Dancy and Sikkink makes a strong case for the effectiveness of human rights mobilization. Much of the most influential human rights scholarship draws on their arguments and data to substantiate the claim that human rights are improving, indicating that the efforts of transnational human rights movements using international and national law can succeed.

For many advocates, this conclusion is both welcome and useful. They often hold to a vision of human rights that is both normative and universal. Human rights norms emerge and prevail at least in part, advocates claim, because they are inherently persuasive to people's innate sense of justice and fairness, given exposure to information and arguments on their behalf. In addition, human rights are accepted when they result from an appropriate, largely voluntary, and substantially consensual process of normative deliberation, such as processes of negotiating and ratifying multilateral treaties. As a result, scholarly theories based on these assumptions study the effects of ratifying treaties, persuading audiences to adopt norms, institutionalizing them, and shaming and punishing violators. ${ }^{42}$ These theories are sometimes based on an analogy to the workings of domestic law and moral social rules. ${ }^{43}$

${ }^{42}$ Keck and Sikkink, Activists Beyond Borders: Advocacy Networks in International Politics; Martha Finnemore and Kathryn Sikkink, "International Norm Dynamics and Political Change," International Organization 52, no. 4 (Autumn 1998): 887-918; Thomas Risse, Stephen C. Ropp, and Kathryn Sikkink (eds.) The Power of Human Rights (Cambridge: Cambridge University Press, 1999).

${ }^{43}$ Sikkink, The Fustice Cascade, 170. 
Thus, the assumptions behind this kind of social science theory of human rights processes and outcomes overlap to a considerable extent with the explicit or implicit assumptions of many human rights organizations themselves. ${ }^{44}$ Indeed, influential scholarship drew lessons from the practices of principled transnational activist networks in the first place to develop causal theories of rights promotion, such as the foundational boomerang, norms cascade, and spiral models, as well as recent work on international law as a lever for empowering rights activism in transitional countries. ${ }^{45}$ Nevertheless, these scholarly, practice-derived accounts of successful mobilization, embedding, and impact increasingly face a range of reservations, questions, and critiques, as we now outline in Section 3.

\section{Human Rights Mobilization and Its Critics}

In this volume, we have grouped the chapters under four broad headings. That the arguments made, and evidence presented, often spills over these artificial boundaries we readily accept. But at the heart of each of the four critiques is a distinct claim: that there are structural impediments to human rights progress (scope conditions), that the scale and intensity of the pushback against human rights is substantial (backlash), that global rights rhetoric too often works at cross-purposes with local social justice priorities (localization), and that the human rights project as a whole is living on borrowed time (utopias and endtimes).

\section{Scope Conditions}

Mainstream approaches traditionally assume considerable leeway for activism to make a difference even in the face of structural impediments. The Power of Human Rights (1999) suggested that the spiral model could work in a broad range of settings, including very poor countries with few facilitating conditions for rights or democracy. The follow-up book organized by the same team, The Persistent Power of Human Rights (2013), has much more to say about the limitations that structural parameters such as the strength of the state place on the action of individuals in promoting or abusing rights, but its message remains that meaningful progress is possible.

Another approach assumes, however, that rights emerge, if at all, from specific configurations of social power. It asks: who has control over

\footnotetext{
${ }^{44}$ Of course, there are many more skeptical practitioners as well who would embrace some aspects of the critiques outlined in Human Rights Futures.

${ }^{45}$ See the references by Sikkink and by Simmons.
} 
resources and rule-setting, what rules are in their interest, and how do they struggle and bargain over the creation of rules and institutions to realize those interests? ${ }^{46}$ If this background social power is too weak to sustain a popular reform coalition then the drive for human rights is like a general without an army.

For example, a standard textbook on the history of rights traces their incremental expansion as a result of social modernization from privileges of armed nobility in such decrees as the Magna Carta, through civil and political rights for urban commercial classes, and finally to social and economic protections for the politically empowered working class. ${ }^{47}$ The research agenda that emerges from these assumptions tends to ask questions about the power, interests, and coalition potential of rightspromoting groups and of rights-abusing "spoilers." Tactically, the research focus is on conditional incentives, political bargaining, and investment in enforcement institutions as precursors to the emergence of rights. ${ }^{48}$ In this view, politics tends to lead; norms tend to follow. Under scope conditions, we ask some searching questions of the norms-led narrative of progress by looking at three sets of structural barriers in more detail.

Snyder, for example, argues that successful movements for change have been backed by well-placed, diversely motivated coalitions of political actors whose existing power and influence can be used to align around rights claims. But these are not necessarily rights-driven actors. ${ }^{49}$ Risse, meanwhile, examines the prospect of human rights observance in areas of limited statehood where the state is unable or unwilling to make its power count.

These accounts remain committed to the successful realization of human rights, but they take a pragmatic view of how that might be achieved. In contrast to the use of shaming, moral condemnation and persuasion, and the pursuit of 'human rights first' (that is, human rights as a process as well as an outcome), pragmatically minded scholars have argued for compromises that include bargaining with powerful spoilers

${ }^{46}$ Michael Mann, The Sources of Social Power, volume II, The Rise of Classes and NationStates, 1760-1914 (Cambridge: Cambridge University Press, 1993), ch. 6, discusses the relationship between structural and normative power in the French Revolution.

47 Ishay, The History of Human Rights.

${ }^{48}$ Hafner-Burton, Making Human Rights a Reality and Emilie Hafner-Burton, Forced to Be Good: Why Trade Agreements Boost Human Rights (Ithaca: Cornell University Press, 2009); Jack Snyder and Leslie Vinjamuri, "Trials and Errors: Principle and Pragmatism in Strategies of International Justice," International Security 28, No. 3 (Winter 2003/ 04): $5-44$.

${ }^{49}$ Hafner-Burton focuses on the necessity of allying rights claims to political power as well, making it clear that without the backing of major states the prospects for improvements in human rights globally are diminished: Hafner-Burton, Making Human Rights a Reality. 
and striking amnesty deals that might reduce rights abuse by helping to consolidate peace. ${ }^{50}$ They argue for the merits of sequencing the pursuit of specific rights or accountability measures, working first to create political or institutional conditions that make rights feasible. ${ }^{51}$ On the geopolitical level, pragmatists stress the value of enlisting support for global advocacy campaigns from rising democratic powers such as India, South Africa, and Brazil, even if this means tailoring themes to their interests and sensibilities. They also accept that human rights progress requires making peace with the use of political and economic power to raise the costs of non-compliance. ${ }^{52}$

Having said this, the normative and the social power approaches are not mutually exclusive, and they do have some overlap. Both envision a role for material coercion, and both are concerned with institutional development. Nonetheless, they tend to prioritize different causal mechanisms in terms of importance and in temporal sequence, and thus make distinguishable empirical predictions that can be tested. Both also realize that there is a particular problem with "hard cases."

If debates about rights tactics sometimes sound like a dialogue of the deaf, one reason may be a failure to be clear about the distinction between easy and hard cases. Much empirical research portrays a division into three distinct worlds of rights compliance: stable democracies, where rights guarantees are routine notwithstanding peculiar "exceptionalisms" and lapses; transitional states with some democratic features and some liberal institutions, where violations may be common but mainstream legal and activist methods can be effective (the "easy cases" for rights promotion); and authoritarian states, where mainstream methods rarely work and alternative methods are not well conceptualized or studied (the "hard cases").

Better locating the dividing line between "easy cases," where mainstream rights methods are promising, and "hard cases," which are beyond

${ }^{50}$ Carolyn M. Moehling, "State Child Labor Laws and the Decline of Child Labor," Explorations in Economic History 36, no. 1 (January 1999): 72-106. For an argument that getting the right result by the wrong means is a violation of rights, not a success for rights, see Kathryn Sikkink, "The Role of Consequences, Comparison and Counterfactuals in Constructivist Ethical Thought," in Richard Price, ed., Moral Limit and Possibility in World Politics (Cambridge, UK: Cambridge University Press 2008), 83-111; Jack Snyder and Leslie Vinjamuri, "Principled Pragmatism and the Logic of Consequences," International Theory. 4, no. 3 (November 2012): 434-48.

${ }^{51}$ Remarks by Kenneth Roth, "Roth: In Syria Peace Talks, Keep Justice - Not Impunity on the Table," International Peace Institute, January 17, 2014, www.ipinst.org/events/pa nel-discussions/details/509-roth-in-syria-peace-talks-keep-justicenot-impunityon-the-ta ble.html; Also, remarks by Aryeh Neier on the Arab Revolutions, European Council on Foreign Relations, London, March 9, 2011.

${ }^{52}$ Hafner-Burton, Making Human Rights a Reality. 
the scope conditions of mainstream theories and methods, would be of great value for scholarship and human rights practice.

\section{Backlash}

Early theories of human rights promotion placed most of their emphasis on the persuasive or coercive initiatives of rights promoters. The targets of influence were typically portrayed as out-argued, out-gunned, or lured down the slippery slope of compliance. Updated versions of the spiral model, however, join the scope conditions, backlash, and localization approaches in acknowledging that rights promotion is often relentlessly contested by actors drawing on a deep well of social, cultural, ideological, material, and geographic resources.

In many of these cases, entrenched and powerful spoilers have pushed back against the encroachment of human rights on their autonomy, sometimes strengthening their domestic base of support by mobilizing alternative value systems, at other times creating alternative venues that bypass rights or reinterpreting the demands of those rights so they no longer conflict with sovereign prerogatives. As human rights advocacy has grown stronger and more intrusive, many state leaders have become increasingly strategic in their response - for example, turning to regional institutions to deflect and restrict international human rights or even to create counternorms (Vinjamuri, and Cooley and Schaaf, this volume).

Backlash is "a behavioral response to the application or clear anticipation of a specific policy or institutional practice that is perceived to be in opposition to the interests or values of a particular actor or set of actors. It is characterized by an attempt to alter, restrict, subvert, or otherwise resist this application of policy or practice" (Vinjamuri, this volume). Backlash does not need to be a direct response to the promotion of human rights norms, in other words, but may be pre-emptive. It may also range from great powers explicitly rejecting the reach of human rights (e.g., Russia, China, and the United States refusing to join the ICC), to medium-sized and smaller powers frustrating the due process of international human rights and international justice processes (e.g., Turkey and Egypt, or Kenya and South Africa over the ICC). Restricting the activities of human rights NGOs (by barring foreign funding, for instance, or changing tax and registration rules) or challenging human rights norms through a countervailing sovereignty and stability discourse are further examples.

In her chapter for this collection, Hurd points to a further irony: the very activities of human rights promoters may bring about a deterioration in the long-term prospects for human rights observance. By advocating 
the right to religious freedom, and thus accentuating the advantages recognition, mobilization, influence - that come with identifying as a religious group, the possibility for conflict over fundamental norms may be enhanced. As an unintended consequence, human rights promotion helps create the very circumstances that it is most keen to avoid.

Advocates for the success of human rights might ask why be so concerned with backlash now - after all, there has always been resistance to human rights from both the left and the right, as well as from religious groups? One explanation is that the very ubiquity of rights, and their use as conditional aspects of global governance and foreign policy prescriptions (e.g., the United States and Venezuela), gives them a power and influence they have only had since the 1990s. They now threaten established authorities in a way they never have before. Moreover, in a world in which China is rising, the international system now has at least one great power (two, if we count Russia) that openly rejects the rights discourse, providing inspiration and diplomatic cover for other resistors.

\section{Localization}

A third approach assumes that, while rights concepts may have analogues in most of the world's cultures, they emerge in local forms using vernacular terminologies in different cultural settings. The research agenda that emerges from this perspective (associated most prominently with Sally Engle Merry, this volume, and Amitav Acharya) asks questions about how local discourses interact with the universalistic language of the contemporary global human rights movement.

These "vernacularizers" or "localizers" of rights have stressed the role of local brokers capable of adapting norms to local cultures. ${ }^{53}$ This is not necessarily a unidirectional process. The current research agenda, while retaining the basic propositions of largely one-way influence models, now routinely accepts that all interactions on rights are two-way (or more likely multi-directional), involving "blocking," "backdooring," "multivocality," and phony compliance with norms of legal accountability (Hertel, this volume) ${ }^{54}$

${ }^{53}$ Peggy Levitt and Sally Engle Merry, "Making Women's Human Rights in the Vernacular: Navigating the Culture/Rights Divide," in Gender and Culture at the Limit of Rights, Dorothy Hodgson (ed.) (Philadelphia: University of Pennsylvania Press, pp. 81-100); Aaron Boesenecker and Leslie Vinjamuri, "Lost in Translation? Civil Society and the Negotiation of International Norms," International fournal of Transitional fustice (Special Issue on Civil Society) 5, no. 3 (2011): 345-65.

${ }^{54}$ In addition to Persistent Power of Human Rights and Shareen Hertel, Unexpected Power: Conflict and Change among Transnational Activists (Ithaca: Cornell University Press, 2006), see Kate Cronin-Furman, "Managing Expectations: International Criminal 
Successful rights promotion outside the West, say advocates of vernacularization, requires more scope for domestic agents to draw on local culture to create normative alternatives that secure autonomy for locals. They need to do this, however, without potential converts to rights becoming alienated from the rights-compatible discourses and practices to which they are already committed. Vernacularization, they note, has been most successful when local brokers are anchored domestically and have good networks abroad that enable them to adapt international norms to local contexts. Grounding international norms in local culture reduces the risk that spoilers will be able to brand rights activists as handmaidens of imperialism. It is even possible to see "American exceptionalism" on this basis as a kind of vernacularization.

In some cases, cultural differences have driven a wedge through transnational human rights networks, separating international advocates from local activists. Human rights norms have failed to gain traction where they seem tangential to solving the most pressing problems, like endemic poverty, underdevelopment, climate change, or disease. In countries where elites can appeal to Islam, evangelical Christianity, and even the Catholic Church, pressures to embrace women's rights have been easily deflected. As a consequence, translating rights ideas into the vernacular may also at times grease a slippery slope toward transgression.

Scholarly research has addressed the effectiveness of different persuasion techniques to enrich and diversify global rights cultures across cultural boundaries, including analyzing both the modalities of decentralization and two-way dialogue. ${ }^{55}$ Merry makes the point that the power of the human rights message for downtrodden constituencies in developing countries stems in large part from the idea that universal ideals propounded by the most powerful, successful societies in the world are being applied to their own situation, no matter what local norms say. Thus, she raises the question of the trade-off in effectiveness between the

Trials and the Prospects for Deterrence of Mass Atrocity," International fournal of Transitional fustice 7, no. 3 (2013): 434-54, first published online August 7, 2013 doi:10.1093/ijt/ijt016; Subotic, Hijacked fustice; Boesenecker and Vinjamuri, "Lost in Translation?"; Amitav Acharya, "Norm Subsidiarity and Regional Orders: Sovereignty, Regionalism, and Rule-Making in the Third World," International Studies Quarterly 55, No. 1 (March 2011): 95-123, and Keck and Sikkink, Activists Beyond Borders, 67-77.

55 Peggy Levitt and Sally Merry, "Vernacularization on the Ground: Local Uses of Global Women's Rights in Peru, China, India, and the United States," Global Networks 9, No. 4 (2009); Amitav Acharya, Rethinking Power, Institutions, and Ideas in World Politics: Whose $I R$ ? (London: Routledge, 2013); Lila Abu Lughod, "Do Muslim Women Really Need Saving? Anthropological Reflections on Cultural Relativism and Its Others," American Anthropologist 104, No. 3 (September 2002): 783-90; Andrew Moravcsik, "The Paradox of U.S. Human Rights Policy," in Michael Ignatieff (ed.) American Exceptionalism and Human Rights (Princeton: Princeton University Press, 2005), 147-97. 
charisma of universality and the ease of adaptation into local language and practice. Like the question of the potential distortion - indeed, perversion - of rights concepts through vernacularization, this subject has been noticed but barely studied, let alone studied in a systematic way that asks when one horn of the dilemma predominates.

Empirical studies of vernacularization so far mainly serve the development and illustration of theory rather than the testing of it. Such illustrative studies include accounts of improvements in grass-roots women's rights practices in India without using rights language, and of the translation of universalistic rights arguments opposing female genital cutting into local Sufi religious doctrine in Senegal. ${ }^{56}$ More mixed results, however, are reported in theory-building case studies of resistance to mainstream international rights frames by local activists in the global South who pursue different rights goals or prefer different kinds of rights justifications. ${ }^{57}$ Similarly, scholars diverge in their estimation of whether local justice initiatives comply with or represent an unsettling departure from international human rights standards. ${ }^{58}$ Finally, rights vernacularization studies also include unsettling accounts of human rights talk being used to justify the lynching of criminals by urban vigilantes as well as torture of suspects by police with special human rights training. ${ }^{59} \mathrm{~A}$ next step for studies of vernacularization may be to specify conditions under which local translation facilitates or undermines adoption of rights thinking.

\section{Utopias and Endtimes}

A final approach to the future of human rights questions both the normative universalism of mainstream rights thinking and the global convergence assumptions of liberal modernization theory. Taking the vernacularization agenda a step further, this approach questions whether the cross-cultural impact of the human rights project is too superficial to thrive in the event of American hegemonic decline and the emergence of

${ }^{56}$ Levitt and Merry, "Vernacularization on the Ground"; Alfred Stepan, "Rituals of Respect: Sufis and Secularists in Senegal in Comparative Perspective," Comparative Politics 44, no. 4 (July 2012): 379-401.

57 See Hertel, Unexpected Power, on blocking in Bangladesh and backdooring in Mexico.

${ }^{58}$ See Phil Clark, The Gacaca Courts and Post-Genocide fustice and Reconciliation in Rwanda: fustice without Lawyers (Cambridge: Cambridge University Press, 2010), and Lars Waldorf, "A Mere Pretense of Justice: Complementarity, Sham Trials, and Victor's Justice at the Rwanda Tribunal," Fordham International Law fournal 33, no. 4 (2010): 1221-77.

59 Daniel Goldstein, Outlawed: Between Security and Rights in a Bolivian City (Durham: Duke University Press, 2012); Rachel Wahl, fust Violence: Torture and Human Rights in the Eyes of the Police (Stanford: Stanford University Press, 2017). 
multiple modernities, including illiberal ones (Hopgood, this volume). It also suggests that Western liberalism has taken a wrong turn, overinvesting in the rights approach to liberal progress and systematically sidelining both ideas (like freedom and equality) and alternative mobilizing principles (national self-determination, socialism) that promise more genuine normative progress (Moyn, this volume).

This research agenda asks whether human rights thinking is an unexportable product of liberal capitalism, whether it lacks the penetration power of earlier forms of cultural imperialism such as Christianity, whether the international human rights movement is recent and superficial, and whether it competes ideologically with and crowds out more promising mass-based movements for social justice ${ }^{60}$ These accounts are more critical of the whole enterprise of human rights. They suggest a future in which the aspiration to human rights is largely restricted to a zone of liberal-democratic states in the West. These accounts doubt the emancipatory potential of the transnational middle class and fear that the challenge to global liberal norms by Russia and China, as well as by populist nationalism in several Western states, including the United States, heralds a permanent reverse for human rights in an increasingly multipolar, even post-Western world. Increased backlash is evidence of existential contestation, in other words.

By monopolizing the liberal approach to freedom, rights have sidelined a much richer tradition of human progress and undermined their own emancipatory potential in the process. Furthermore, given the forces now arrayed against human rights, the narrow cultural roots of their underlying conception of the person and the distributional consequences they entail for equality in society are becoming clearer.

\section{Conclusion}

Contemporary rights practitioners have actively debated how to respond to these challenges, just as scholars have worked hard to figure out how to measure them. Many practitioners favor retaining a core focus on civil and political rights, a central role for legal tools in rights promotion, and adherence to universal standards. For many scholars and also advocates, the rights project is a long-term game; pushback and hypocrisy are inevitable, but temporary, setbacks. Growing participation in rights promotion by non-Western activists is an important objective, they agree, but not at the expense of watering down core principles. Others argue that

${ }^{60}$ Moyn, Last Utopia; Hopgood, Endtimes. 
pragmatism is a realistic necessity in a world that's very different from that of the 1970s or even the 1990s.

To paraphrase Santayana, to get where you want to go you need to know where you have been, or at least your direction of travel. This is the spirit in which this volume was assembled. The chapters are written by scholars in political science, history, and anthropology whose work has shaped the development of debates about human rights over the past two decades. Our hope is to try to see the future through analyses of human rights that are rooted firmly in their past and present circumstances. We have seen that significant differences exist within the worlds of human rights advocacy and scholarship on a number of issues and these can be simplified into three questions: Have human rights improved? If so, why have they improved (and if not, why not)? And what are the alternatives to business as usual? Should we do more of the same in tackling hard cases, should we be more savvy (or cut our losses), or should we do something else entirely? There could hardly be more pressing questions to ask in the changing world we live in. 